\title{
Preparation and Crystal Structure of the Mercury(I) Dimolybdate(VI) $\mathrm{Hg}_{2} \mathrm{Mo}_{2} \mathrm{O}_{7}$
}

\begin{abstract}
Annemarie L. Wessels, Wolfgang Jeitschko*
Anorganisch-Chemisches Institut der Universität Münster, Wilhelm Klemm-Straße 8, D-48149 Münster, Germany

Dedicated to Prof. Dr. Gerhard Thiele on the occasion of his 60th birthday

Z. Naturforsch. 51b, 37-41 (1996); received May 22, 1995

Crystal Structure, Magnetic Susceptibility, Mercury Molybdates(VI)

Yellow, flat, needle-shaped, diamagnetic crystals of $\mathrm{Hg}_{2} \mathrm{Mo}_{2} \mathrm{O}_{7}$ were obtained by decomposition of $\mathrm{Hg}_{2} \mathrm{MoO}_{4}$ in evacuated, sealed silica tubes at $550{ }^{\circ} \mathrm{C}$. Their crystal structure was determined from four-circle diffractometer data: $\mathrm{P} \overline{1}, a=709.7(2), b=714.4(2), c=803.8(2)$ pm, $\alpha=64.89(1)^{\circ}, \beta=66.09(1)^{\circ}, \gamma=66.45(1)^{\circ}, Z=2, R=0.030$ for 3165 structure factors and 66 variables. The molybdenum atoms are coordinated by four oxygen atoms at 171 to $195 \mathrm{pm}$ in a very distorted tetrahedral arrangement. These tetrahedra are linked via a common oxygen atom, thus forming $\mathrm{Mo}_{2} \mathrm{O}_{7}$ groups. The tetrahedral oxygen coordination of each molybdenum atom is augmented by two additional oxygen atoms at 218 to $231 \mathrm{pm}$, which leads to a distorted octahedral coordination for the molybdenum atoms. These $\mathrm{MoO}_{6}$ octahedra are connected via common corners and edges and in this way they form two-dimensionally infinite sheets, which are separated by the $\mathrm{Hg}_{2}$ pairs $(\mathrm{Hg}-\mathrm{Hg}$ distance: $252.2 \mathrm{pm})$.
\end{abstract}

\section{Introduction}

Only few mercury molybdates are known. $\mathrm{Hg}_{2} \mathrm{MoO}_{4}$ was first described by Berzelius and later by Lelubre [1]. Gupta and Saxena investigated the influence of the $\mathrm{pH}$ value on the precipitation of $\mathrm{HgMoO}_{4}[2,3]$ and $\mathrm{Hg}_{2} \mathrm{MoO}_{4}[4,5]$. The synthesis of $\mathrm{HgMoO}_{4}$ was also described by Sleight and Licis [6] and by Blasse [7], and its crystal structure was determined $[8,9]$. The synthesis of three unstable mercury peroxomolybdate hydrates was reported by Bogdanov, Savina, and Petrova [10].

Here we describe the preparation of $\mathrm{Hg}_{2} \mathrm{Mo}_{2} \mathrm{O}_{7}$, for which we find a new triclinic structure type. A light yellow, flocculent precipitate of this composition was first mentioned by Struve in 1853 and 1854 [11], however it was not further characterized. A preliminary account of the presently reported results has been given at a conference [12].

\section{Sample Preparation and Properties}

Starting materials were $\mathrm{Na}_{2} \mathrm{MoO}_{4} \cdot 2 \mathrm{H}_{2} \mathrm{O}$ (Riedel-de Haën, 99.5\%) and $\mathrm{Hg}_{2}\left(\mathrm{NO}_{3}\right)_{2} \cdot 2 \mathrm{H}_{2} \mathrm{O}$ (Merck, 98\%). These compounds were reacted in aqueous solution to form a precipitate of $\mathrm{Hg}_{2} \mathrm{MoO}_{4}$, which was dried in a vacuum desiccator

\footnotetext{
* Reprint requests to W. Jeitschko.
}

over calcium chloride for two days [2, 3]. Ca. $0.4 \mathrm{~g}$ of this compound were then sealed in evacuated silica tubes of about 4 to $6 \mathrm{~cm}^{3}$ and annealed at $550{ }^{\circ} \mathrm{C}$ for one week. The samples were cooled to $300^{\circ} \mathrm{C}$ within five hours and then quenched in air. Visible reaction products are yellow, sometimes up to $7 \mathrm{~mm}$ long, needle-shaped crystals of $\mathrm{Hg}_{2} \mathrm{Mo}_{2} \mathrm{O}_{7}$, the previously characterized compound $\mathrm{HgMoO}_{4}$ [6-9] in microcrystalline as well as in good crystallized form, and metallic mercury. Apparently the decomposition proceeds by the equations $4 \mathrm{Hg}_{2} \mathrm{MoO}_{4} \rightarrow 2 \mathrm{Hg}_{2} \mathrm{Mo}_{2} \mathrm{O}_{7}+4 \mathrm{Hg}+\mathrm{O}_{2}$ and $\mathrm{Hg}_{2} \mathrm{MoO}_{4} \rightarrow \mathrm{HgMoO}_{4}+\mathrm{Hg}$. The second reaction is favoured at higher temperatures. Occasionally we have obtained $\mathrm{MoO}_{3}$ and another yet unidentified mercury molybdate.

In microcrystalline form $\mathrm{Hg}_{2} \mathrm{Mo}_{2} \mathrm{O}_{7}$ is light yellow, the needles have a color like elemental sulfur, in contrast to $\mathrm{HgMoO}_{4}$, which is white in microcrystalline form and colorless in the form of the small crystals, which we obtained, while larger crystals are reported to be light yellow [6].

The magnetic susceptibility of $\mathrm{Hg}_{2} \mathrm{Mo}_{2} \mathrm{O}_{7}$ was determined with a SQUID magnetometer. The sample is diamagnetic with a susceptibility of $\chi=$ $(-1.4 \pm 0.3) \cdot 10^{-9} \mathrm{~m}^{3} / \mathrm{mol}$.

The lattice constants (Table I) were obtained by a least-squares fit of Guinier powder data. $\mathrm{CuK} \alpha_{1}$ radiation was used with $\alpha$-quartz ( $a=491.30 \mathrm{pm}$, $c=540.46 \mathrm{pm})$ as an internal standard. 
Table I. Crystal data for $\mathrm{Hg}_{2} \mathrm{Mo}_{2} \mathrm{O}_{7}$. Standard deviations in the positions of the least significant digits are given in parentheses throughout the paper.

\begin{tabular}{|c|c|c|}
\hline \multirow{2}{*}{\multicolumn{3}{|c|}{$\begin{array}{l}\text { Space group P } \mathrm{P} \overline{1} \text { (No. } 2) \\
\text { Lattice constants from Guinier powder [and single crys- } \\
\text { tall data }\end{array}$}} \\
\hline & & \\
\hline$a[\mathrm{pm}]$ & $709.7(2)$ & [709.1(1)] \\
\hline$b[\mathrm{pm}]$ & $714.4(2)$ & {$[713.3(1)]$} \\
\hline$c[\mathrm{pm}]$ & $803.8(2)$ & {$[802.9(1)]$} \\
\hline$\alpha\left[^{\circ}\right]$ & $64.89(1)$ & {$[64.85(1)]$} \\
\hline$\beta\left[^{\circ}\right]$ & $66.09(1)$ & {$[66.10(1)]$} \\
\hline$\gamma[0]$ & $66.45(1)$ & {$[66.50(2)$} \\
\hline$V\left[\mathrm{~nm}^{3}\right]$ & 0.3244 & {$[0.3233]$} \\
\hline Formula units/cell & $Z=2$ & \\
\hline Formula weight & 705.06 & \\
\hline Calculated density $\left[\mathrm{g} / \mathrm{cm}^{3}\right]$ & 7.22 & \\
\hline Crystal size $\left[\mu \mathrm{m}^{3}\right]$ & $40 \times 50 \times 70$ & \\
\hline$\theta / 2 \theta$ scans up to & $2 \theta=84^{\circ}$ & \\
\hline Range in $h k l$ & $\pm 13, \pm 13, \pm 15$ & \\
\hline Highest/lowest transmission & 1.41 & \\
\hline Total number of reflections & 9030 & \\
\hline \multicolumn{3}{|c|}{ Absorption correction from psi scans } \\
\hline Unique reflections & 4515 & \\
\hline Inner residual & $R_{\mathrm{i}}=0.035$ & \\
\hline Reflections with $\mathrm{I}_{\mathrm{o}}>3 \sigma\left(\mathrm{I}_{\mathrm{o}}\right)$ & 3165 & \\
\hline Number of variables & 66 & \\
\hline Conventional residual & $R=0.030$ & \\
\hline Weighted residual & $R_{w}=0.037$ & \\
\hline
\end{tabular}

\section{Structure Determination}

Single-crystals of $\mathrm{Hg}_{2} \mathrm{Mo}_{2} \mathrm{O}_{7}$ were examined in a Weissenberg camera to establish their suitability for the intensity data collection. The lattice constants obtained from the four-circle diffractometer (Table I) were slightly smaller than those from the Guinier film data, because of systematic errors due to absorption. Therefore the latter are considered more reliable. The intensity data were mea- sured on an Enraf-Nonius CAD 4 diffractometer with graphite-monochromated MoK $\alpha$ radiation, a scintillation counter with pulse-height discriminator, and background counts on both ends of each $\theta / 2 \theta$ scan. An absorption correction was made from psi scan data. Further details are summarized in Table I.

$\mathrm{Hg}_{2} \mathrm{Mo}_{2} \mathrm{O}_{7}$ has triclinic symmetry and the structure was refined in the centrosymmetric group $\mathrm{P} \overline{1}$. The positions of some metal atoms were obtained from a Patterson synthesis and the other atoms were located by difference Fourier syntheses. The structure was refined by a full-matrix least-squares program using atomic scattering factors [13], corrected for anomalous dispersion [14]. The weighting scheme provided for the counting statistics and a parameter correcting for isotropic secondary extinction was optimized as a least-squares variable. In the final least-squares cycles the metal atoms were refined with anisotropic and the oxygen with isotropic displacement parameters. A final difference Fourier synthesis did not give any indications for the occupancy of additional atomic sites. The structure factor tables are available from the authors [15]. The atomic parameters and interatomic distances are listed in the Tables II and III.

\section{Discussion}

The new mercury molybdate crystallizes with a novel structure type. The compound may be formulated as $\left[\mathrm{Hg}_{2}^{2+}\right]\left[\mathrm{Mo}_{2} \mathrm{O}_{7}^{2-}\right]$, indicating the oxidation numbers +1 and +6 for the mercury and the molybdenum atoms, respectively. The two dif-

Table II. Atomic parameters of $\mathrm{Hg}_{2} \mathrm{Mo}_{2} \mathrm{O}_{7}$. The fifth column contains the isotropic displacement parameters of the oxygen atoms and the equivalent isotropic $\mathrm{B}$ values of the metal atoms in units of $10^{-2} \mathrm{~nm}^{2}$. The anisotropic displacement parameters have the form $\exp \left[-0.25 \cdot\left(h^{2} a^{* 2} \mathrm{~B}_{11}+\ldots+k l b^{*} c^{*} \mathrm{~B}_{23}\right)\right]$.

\begin{tabular}{|c|c|c|c|c|c|c|c|c|c|c|}
\hline Atom & $x$ & $y$ & $z$ & B & $\mathrm{B}_{11}$ & $\mathrm{~B}_{22}$ & $\mathrm{~B}_{33}$ & $\mathrm{~B}_{12}$ & $\mathrm{~B}_{13}$ & $\mathrm{~B}_{23}$ \\
\hline $\mathrm{Hg} 1$ & $0.19023(3)$ & $0.32561(3)$ & $0.36437(3)$ & $1.074(3)$ & $1.298(4)$ & $1.368(5)$ & $0.792(4)$ & $-0.467(3)$ & $-0.730(3)$ & $-0.045(3)$ \\
\hline $\mathrm{Hg} 2$ & $0.37441(3)$ & $0.18055(3)$ & $0.62200(3)$ & $1.165(4)$ & $1.350(4)$ & $1.548(5)$ & $0.773(5)$ & $-0.476(3)$ & $-0.733(3)$ & $-0.040(4)$ \\
\hline Mo 1 & $0.30011(5)$ & $0.88204(6)$ & $0.11810(6)$ & $0.477(6)$ & $0.469(7)$ & $0.556(8)$ & $0.510(9)$ & $-0.221(5)$ & $-0.144(6)$ & $-0.180(6)$ \\
\hline Mo 2 & $0.80974(5)$ & $0.37535(6)$ & $0.13540(6)$ & $0.473(6)$ & $0.500(7)$ & $0.550(7)$ & $0.495(9)$ & $-0.242(5)$ & $-0.165(6)$ & $-0.161(6)$ \\
\hline O 1 & $0.0343(5)$ & $0.4503(5)$ & $0.1542(5)$ & $0.73(5)$ & & & & & & \\
\hline $\mathrm{O} 2$ & $0.1056(5)$ & $0.1101(6)$ & $0.0401(6)$ & $0.83(5)$ & & & & & & \\
\hline $\mathrm{O} 3$ & $0.1674(6)$ & $0.7651(7)$ & $0.3488(6)$ & $1.30(6)$ & & & & & & \\
\hline $\mathrm{O} 4$ & $0.4585(5)$ & $0.0098(5)$ & $0.1646(5)$ & $0.75(5)$ & & & & & & \\
\hline O5 & $0.5933(6)$ & $0.5970(6)$ & $0.1773(6)$ & $0.94(5)$ & & & & & & \\
\hline O6 & $0.6983(6)$ & $0.2970(6)$ & $0.0035(6)$ & $0.94(5)$ & & & & & & \\
\hline O 7 & $0.7735(6)$ & $0.1792(7)$ & $0.3516(6)$ & $1.32(6)$ & & & & & & \\
\hline
\end{tabular}


Table III. Interatomic distances in the structure of $\mathrm{Hg}_{2} \mathrm{Mo}_{2} \mathrm{O}_{7}$. All distances shorter than $330 \mathrm{pm}(\mathrm{Hg}-\mathrm{Hg}$, $\mathrm{Hg}-\mathrm{Mo}$, Mo-Mo, $\mathrm{Hg}-\mathrm{O}, \mathrm{Mo}-\mathrm{O})$ and $260 \mathrm{pm}$ $(\mathrm{O}-\mathrm{O})$ are listed. The standard deviation of the $\mathrm{Hg}-\mathrm{Hg}$ bondlength is $0.1 \mathrm{pm}$; for the other distances the standard deviations vary between 0.4 and $0.7 \mathrm{pm}$.

\begin{tabular}{|c|c|c|c|c|c|}
\hline \multirow[t]{6}{*}{ Hg 1: } & $\mathrm{Hg} 2$ & 252.2 & \multirow[t]{4}{*}{ O1: } & Mo 2 & 194.8 \\
\hline & O1 & 207.9 & & $\mathrm{Hg} 1$ & 207.9 \\
\hline & O3 & 273.5 & & Mo2 & 217.9 \\
\hline & $\mathrm{O} 4$ & 290.9 & & (O1 & 246.9) \\
\hline & O3 & 303.0 & \multirow[t]{3}{*}{ O2: } & Mo1 & 172.9 \\
\hline & O6 & 311.2 & & Mo2 & 231.0 \\
\hline \multirow[t]{6}{*}{ Hg 2: } & $\mathrm{Hg} 1$ & 252.2 & & $\mathrm{Hg} 2$ & 305.3 \\
\hline & $\mathrm{O} 4$ & 213.9 & \multirow[t]{3}{*}{ O3: } & Mo 1 & 171.0 \\
\hline & O7 & 278.4 & & $\mathrm{Hg} 1$ & 273.5 \\
\hline & O 5 & 281.9 & & $\mathrm{Hg} 1$ & 303.0 \\
\hline & O7 & 304.4 & \multirow[t]{5}{*}{ O4: } & Mo 1 & 192.0 \\
\hline & $\mathrm{O} 2$ & 305.3 & & $\mathrm{Hg} 2$ & 213.9 \\
\hline \multirow[t]{6}{*}{ Mo1: } & O3 & 171.0 & & Mo 1 & 226.0 \\
\hline & $\mathrm{O} 2$ & 172.9 & & $\mathrm{Hg} 1$ & 290.9 \\
\hline & O 6 & 190.6 & & $(\mathrm{O} 4$ & 252.1) \\
\hline & $\mathrm{O} 4$ & 192.0 & \multirow[t]{3}{*}{ O5: } & Mo 2 & 175.2 \\
\hline & $\mathrm{O} 4$ & 226.0 & & Mo 1 & 230.1 \\
\hline & O5 & 230.1 & & $\mathrm{Hg} 2$ & 281.9 \\
\hline \multirow[t]{6}{*}{ Mo 2: } & O 7 & 170.5 & \multirow[t]{3}{*}{ O6: } & Mo 2 & 189.7 \\
\hline & O5 & 175.2 & & Mo1 & 190.6 \\
\hline & O 6 & 189.7 & & $\mathrm{Hg} 1$ & 311.2 \\
\hline & O 1 & 194.8 & \multirow[t]{3}{*}{ O 7: } & Mo 2 & 170.5 \\
\hline & $\mathrm{O} 1$ & 217.9 & & $\mathrm{Hg} 2$ & 278.4 \\
\hline & $\mathrm{O} 2$ & 231.0 & & $\mathrm{Hg} 2$ & 304.4 \\
\hline
\end{tabular}

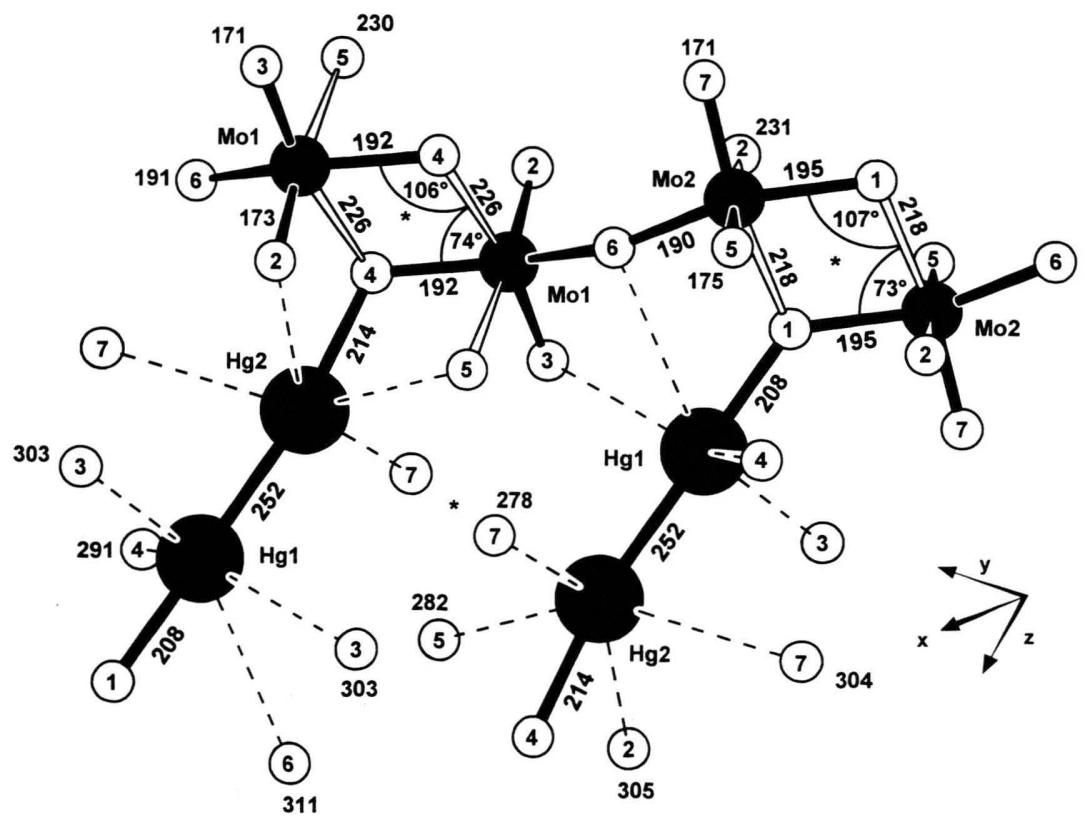

Fig. 1. Near-neighbor environments in the structure of $\mathrm{Hg}_{2} \mathrm{Mo}_{2} \mathrm{O}_{7}$. The molybdenum atoms have four oxygen neighbors (filled bonds) at distances between 171 and $195 \mathrm{pm}$ in very distorted tetrahedral arrangements. With two more oxygen atoms (open bonds) the coordinations become distorted octahedral. One-digit numbers correspond to the designation of the oxygen atoms. The location of some centers of symmetry are indicated by asterisks. 


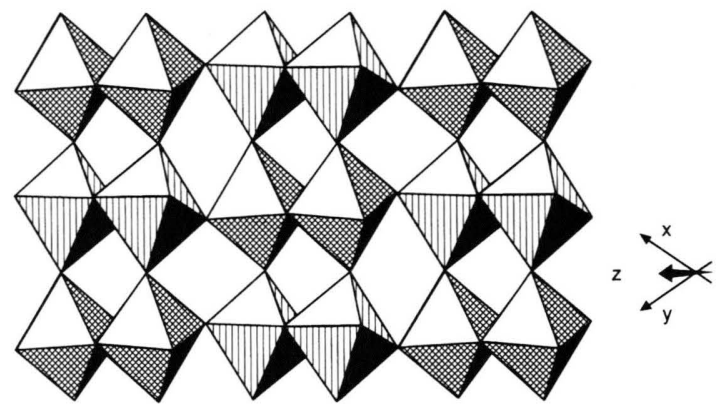

Fig. 2. The packing of the corner- and edge-sharing $\mathrm{MoO}_{6}$ octahedra in the two-dimensionally infinite $\mathrm{Mo}_{2} \mathrm{O}_{7}$ layers of $\mathrm{Hg}_{2} \mathrm{Mo}_{2} \mathrm{O}_{7}$.

O 6 atoms belong to corner sharing octahedra. The remaining oxygen atoms (O3 and $\mathrm{O} 7)$ belong to only one molybdenum atom. They have two mercury neighbors, while the others have one with the exception of the $\mathrm{O} 4$ atom, which has two molybdenum and two mercury neighbors.

The two-dimensionally infinite sheets of linked $\mathrm{MoO}_{6}$ octahedra of $\mathrm{Hg}_{2} \mathrm{Mo}_{2} \mathrm{O}_{7}$ are connected in the third dimension via $\mathrm{Hg}_{2}$ pairs (Fig. 3). Both mercury atoms are strongly bonded to one mercury and one oxygen atom in nearly linear arrangement ( $\mathrm{Hg} 2-\mathrm{Hg} 1-\mathrm{O} 1: \quad 178.8(1)^{\circ}, \quad \mathrm{Hg} 1-\mathrm{Hg} 2-\mathrm{O} 4:$ $\left.167.3(1)^{\circ}\right)$ as is frequently observed for $\mathrm{Hg}(\mathrm{I})$ atoms. The short $\mathrm{Hg}-\mathrm{O}$ bonds of 207.9 and
213.9 pm compare well with the analogous bond distances of: 209(2), 211(2), 213(2), 215(2), and $222(2) \mathrm{pm}$ in $\left[\left(\mathrm{Hg}_{2}\right)_{5}(\mathrm{OH})_{4}\left(\mathrm{NO}_{3}\right)_{2}\right]\left(\mathrm{NO}_{3}\right)_{4}$ [19], 212(2), 219(2), 224(4), and 231(2) pm in $\left[\left(\mathrm{Hg}_{2}\right)_{2} \mathrm{O}\left(\mathrm{NO}_{3}\right)\right] \mathrm{NO}_{3} \cdot \mathrm{HNO}_{3}$ [19], 213(2) pm in $\mathrm{Hg}_{2}\left(\mathrm{NO}_{3}\right)_{2} \cdot 2 \mathrm{H}_{2} \mathrm{O}$ [20], 213.5(7) and 214.3(7) pm in $\mathrm{Hg}_{2} \mathrm{ReO}_{5}$ [21], 213.6(9) pm in $\mathrm{Hg}_{4} \mathrm{O}_{2}\left(\mathrm{NO}_{3}\right)_{2}$ [22], and 214(3) pm in $\mathrm{Hg}_{2}\left(\mathrm{CF}_{3} \mathrm{CO}_{2}\right)_{2}$ [23]. In these compounds the $\mathrm{Hg}-\mathrm{Hg}$ distances cover the range from 249.5(1) pm in $\left[\left(\mathrm{Hg}_{2}\right)_{5}(\mathrm{OH})_{4}\left(\mathrm{NO}_{3}\right)_{2}\right]\left(\mathrm{NO}_{3}\right)_{4}$ to 252.1(1) pm in $\mathrm{Hg}_{2} \mathrm{ReO}_{5}$ with an average of $250.7 \mathrm{pm}$. These values are only marginally smaller than the $\mathrm{Hg}-\mathrm{Hg}$ distance of 252.2(1) pm in the present investigation for $\mathrm{Hg}_{2} \mathrm{Mo}_{2} \mathrm{O}_{7}$. All of these $\mathrm{Hg}-\mathrm{Hg}$ distances correspond to a bond valence of approximately one [24].

\section{Acknowledgement}

We thank Mrs. U. Rodewald for the competent data collection on the four-circle diffractometer and Mr. K. Wagner for the work at the scanning electron microscope. Dr. M. Danebrock was so kind to determine the magnetic susceptibility of $\mathrm{Hg}_{2} \mathrm{Mo}_{2} \mathrm{O}_{7}$. We are obliged to Dr. G. Höfer (Heraeus Quarzschmelze) for a generous gift of silica tubes. This work was supported by the Deutsche Forschungsgemeinschaft and the Fonds der Chemischen Industrie.
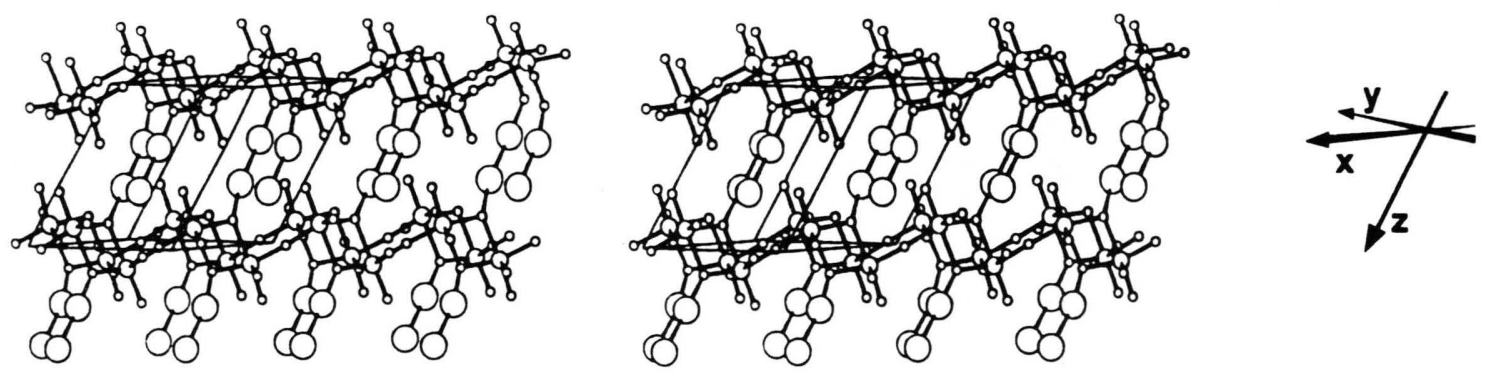

Fig. 3. Stereoplot of the $\mathrm{Hg}_{2} \mathrm{Mo}_{2} \mathrm{O}_{7}$ structure. 
[1] Gmelin Handbuch der Anorganischen Chemie, 53: Molybdän B 2, 8th Edit., Springer, Berlin (1976).

[2] C. M. Gupta, R. S. Saxena, Z. Naturforsch. 13b, 557 (1958).

[3] C. M. Gupta, R. S. Saxena, J. Indian Chem. Soc. 35, 617 (1958).

[4] C. M. Gupta, R. S. Saxena, J. Inorg. Nucl. Chem. 14, 297 (1960).

[5] R. S. Saxena, C. M. Gupta, Naturwissenschaften 47, 201 (1960).

[6] A. W. Sleight, M. S. Licis, Mater. Res. Bull. 6, 365 (1971).

[7] G. Blasse, J. Inorg. Nucl. Chem. 37, 97 (1975).

[8] W. Jeitschko, A. W. Sleight, Z. Naturforsch. 27b, 203 (1972).

[9] W. Jeitschko, A. W. Sleight, Acta Crystallogr. B 29, 869 (1973).

[10] G. A. Bogdanov, M. V. Savina, G. L. Petrova, Zh. Fiz. Khim. 37, 1258 (1963); Russ. J. Phys. Chem. 37, 671 (1963).

[11] Gmelins Handbuch der Anorganischen Chemie, 53: Molybdän, 8th Edit., Verlag Chemie, Weinheim (1935).

[12] A. L. Wessels, W. Jeitschko, Z. Kristallogr. Suppl. 8, 436 (1994).
[13] D. T. Cromer, J. B. Mann, Acta Crystallogr. A 24, 321 (1968).

[14] D. T. Cromer, D. Liberman, J. Chem. Phys. 53, 1891 (1970).

[15] A. L. Wessels, Diplomarbeit, Universität Münster (1993).

[16] B. M. Gatehouse, R. Same, J. Solid State Chem. 25, 115 (1978).

[17] B. M. Gatehouse, P. Leverett, J. Chem. Soc., Dalton Trans. 1976, 1316 (1976).

[18] G. D. Fallon, B. M. Gatehouse, J. Solid State Chem. 44, 156 (1982).

[19] B. Kamenar, D. Matković-Čalogović, A. Nagl, Acta Crystallogr. C42, 385 (1986).

[20] D. Grdenić, M. Sikirica, I. Vicković, Acta Crystallogr. B 31, 2174 (1975).

[21] M. S. Schriewer-Pöttgen, W. Jeitschko, Z. Anorg. Allg. Chem. 620, 1855 (1994).

[22] K. Brodersen, G. Liehr, G. Schottner, Z. Anorg. Allg. Chem. 531, 158 (1985).

[23] M. Sikirica, D. Grdenić, Acta Crystallogr. B 30, 144 (1974).

[24] I. D. Brown, R. J. Gillespie, K. R. Morgan, Zin Tun, P. K. Ummat, Inorg. Chem. 23, 4506 (1984). 